\title{
APPLICATION OF WORK SAFETY STANDARDS FOR SLAB CONSTRUCTION
}

\section{Sebastião Theoto Ramos Corrêa ${ }^{1}$, David Barbosa de Alencar ${ }^{2}$, Camily Murrieta Vasconcelos Oliveira Bezerra ${ }^{3}$ and Luiz Cláudio Menezes Atayde ${ }^{4}$}

\author{
1,2 Blauro Cardoso de Mattos Higher Education Institute - FASERRA. Manaus-Amazonas, Brazil. \\ ${ }^{3,4}$ Nilton Lins University. Manaus-Amazonas, Brazil.
}

Email: stheoto@hotmail.com, david002870@hotmail.com, camilymv@hotmail.com, claudioatayde@hotmail.com

Received: Aug 20th 2019

Accepted: Aug 30th 2019

Published: December 02 ${ }^{\text {th }}, 2019$

Copyright (C2016 by authors and Galileo Institute of Technology and Education of the Amazon (ITEGAM).

This work is licensed under the Creative Commons Attribution International License (CC BY 4.0).

https://creativecommons.org/licen ses/by/4.0/

\begin{abstract}
The slabs, as it is a project above 2 meters must be aligned with the NRs, so that no accidents occur with workers during the execution of the project. Given the above, this research aims to: Analyze the Work Safety Standards for Slab Execution and as specific objectives: Contextualize civil construction; To show the problems of construction with respect to safety at work; Highlight work safety standards for slab execution. It was found that the use of NRs in the Lajes construction process is important, so that no accidents occur in the work environment, as well as during the entire construction process. In the construction process as a whole. The use of IPEs is proven to be highly relevant to avoid work accidents, as well as the lectures and guidance given by professionals to civil construction workers.
\end{abstract}

Keywords: Construction; Regulatory Standards; Slabs.

\section{INTRODUTION}

Civil construction is one of the fastest growing sectors and with this growth arise the respective problems: how the use of Regulatory Standards (NR) in the construction site and its supervision and implementation by professionals.

Thus, for [1] "construction, with the warming of the national economy, is one of the fastest growing sectors in the whole country. Along with the highlight that this sector has been presenting ", according to the author, there is also the concern with their respective problems, such as environmental degradation, waste of raw material, lack of qualification of professionals, scarcity of labor, the Work Safety Regulatory Standards (NR) that need to be enforced, especially in the execution of slabs.

The design of a slab to be reclaimed must be in accordance with NR 6, where it requires construction companies to distribute Personal Protective Equipment (PPE) to construction workers. Also, in accordance with NR 35, it establishes the requirements for the safety of activities performed at heights - that is, those performed above two meters above ground level, where there is a risk of falling.
The slabs, as it is a project above 2 meters, must be aligned with the NRs, so that no accidents occur with the workers during the project execution, as well as any other occupational accident related disorder.

Given the above, this research aims to: Analyze the Work Safety Standards for Slab Execution and as specific objectives: Contextualize civil construction; Show the problems of construction, regarding safety at work; Highlight work safety standards for slab execution.

This is a bibliographic research based on studies in books, articles and magazines already published, which portray this theme.

Therefore, its relevance to academia is an outline that will serve and contribute to new questions and studies aimed at this context. For the professional, the importance of being in the execution of the NRs, as well as the knowledge of them to put into practice when working with the Lajes project. For society, to be in the context of a work constructed safely and enlightened about the real NRs of the worker, because it needs to have knowledge for the construction of slabs. 


\section{LITERATURE REVIEW}

\section{1 THE CIVIL CONSTRUCTION INDUSTRY}

The construction industry has had a strong growth in recent years, in this sense in the studies by [1], "signaling the strong growth of the construction industry in recent years has caused a mismatch between supply and demand for skilled workers".

According to [2], "civil construction is an activity that involves a large number of variables, being developed in a particularly dynamic and changing environment, which makes managing a work a complex work". In this sense, civil construction is an activity developed in a dynamic and changing environment, which is of high complexity.

For [3] the construction industry is one of the most suitable sectors to help combat unemployment that plagues the country. According to the authors, this is because it employs people with low level of Education and training, making use of their physical capacity, allowing access to the labor market of workers completely disqualified very quickly.

The construction industry sector creates jobs directly or indirectly, which favor the country's economy According to [1], "construction is an industry sector that absorbs a significant number of workers through direct or indirect jobs. , having fundamental importance for the economy of the country".

In Brazil there has been a growth in the area of construction, According to sources from the Brazilian government the construction sector in Brazil showed a growth of $11.60 \%$ in 2010 and it is expected that in 2011 we will have a growth approximately $6 \%$, among which we can mention the creation of the Growth Acceleration Program (PAC) [4]. This was due to sporting events such as the World Cup Olympics, increased purchasing power of the Brazilian population, improved infrastructure of cities and many others.

This increase and / or growth is occurring due to the warming of the sector caused by several factors, according to [5]. was able to supply this offer ". In this sense, growth in the area of construction However, the demand is failing to meet the need for hiring its employees.

For [6], "Currently, in the northern region of Brazil, there are on average 10,949 contracted enterprises. In addition to this volume of works, specific characteristics of the State of Pará justify this research ", according to the authors, namely a large territorial extension; limited use of modes of transport; long distances between supplier and consumer centers; and the scarcity of resources (labor and materials) in the civil construction segment. Companies in this segment have strong investments.

Companies have opportunities to invest in business planning, not just in the planning of works. The adoption of integrated management and decision making models that help define and monitor business indicators, productivity and risks [7]. Thus, such approaches also help to reduce operating costs and optimize resources. The adoption of new management methods is also considered a priority for the company.

There are major changes in this segment, however this sector was built by hand as indicated by [8], "the Brazilian civil construction sector was built by the hands of mostly illiterate and unskilled workers, now the sector pays price of years without investments in staff training ". In this sense, it is clear that the lack of responsibility regarding the commitment stems from several factors, as it is up to the workers the duty not to miss work, as well as to try to do it professionally, so that the work is delivered on time. requested and planned.

\section{II.2 PROBLEMS THAT ARE COMMON IN CIVIL CONSTRUCTION}

Construction methods that do not keep up with technological development, is the biggest problem of civil construction According to [9], "says that the biggest problem of construction in Brazil is that construction methods did not keep up with the technological development of the area".

The difficulty in getting new quality workers generates a problem that affects the construction industry, for [10], "the problem that affects the construction industry is the difficulty of attracting new workers in quantity and quality, a study carried out to The Construction Industry Institute, Texas USA "asked students about to graduate from high school, which career path they would like to pursue, 250 job options were presented, and working on a construction site was ranked 248.

According to [11], "currently one of the main bottlenecks present in the construction companies has been the lack of qualified manpower to perform the various services performed at different stages of the works".

In studies by [12], "the difficulties encountered in the design phase can cause irreparable damage to both the designer and the builder, so understanding between the parties involved is important," in this case, project team and team According to the author, the phase of construction projects is a fundamental part of the development of a project and mitigating such problems is important to everyone.

Good management in project design, manpower, project execution, construction logistics, and others, helps to avoid problems, as in the Construction sector, it is not uncommon to identify expenses above budget, late deliveries, conflicts with customers and suppliers [10]. In most of these enterprises, the problem is only identified during the execution, but it originated during the planning phase, but it was not possible to notice.

Good management avoids several problems in the realization of the construction project, as [10] points out., "Good management of the supply sector is critical to controlling the quality of materials and avoiding delays in procurement and delivery."

For [10], "a material purchase planning, availability studies, pre-order strategy, requisition processing / control, relationship between various sectors and functions, receipt control, guarantee of deadlines for all supply management activities are essential."

Concerning the electrical, hydraulic, fire and gas installation projects, [13] "says that this construction process suffers a great interference from other subsystems such as masonry, electrical installations, air conditioning and even the structure itself'. The author also points out that in addition, there are problems related to misuse after occupation and problems inherent in the material used.

\section{II.3 SAFETY AT WORK: A CHALLENGE IN CIVIL CONSTRUCTION}

Execution failures due to plant incompatibilities are the other problem generator and can cause serious delays in the work, with a high degree of rework and design changes already in progress. In order to avoid these failures, several strategies and new methodologies are needed in the civil construction segment, as this is the only way for the company to succeed in its projects. Also, the issue of occupational safety can present difficulties during the construction process as indicated by [14]: 
It can also be seen that many of the requirements of NR18 are met due to action planning and awareness of its importance. Another important finding concerns the standardization of safety in construction companies, showing that the degree of concern about safety issues is related to the individual attitude of workers, as well as a well-executed safety policy (p.6).

Thus, standardization with regard to work safety is very important, as it highlights the company's great concern regarding the safety of workers during the construction of projects as a whole.

The team that makes up the Specialized Service in Safety Engineering and Occupational Medicine (SESMT), aware of this issue, should develop measures to protect and promote the health and well-being of all workers [15]. Through lectures and educational campaigns, addressing occupational hazards inherent in the work task and the correct use of personal protective equipment (PPE), they can avoid these minor problems.

According to [16], construction is one of the most dynamic sectors of the Brazilian economy, employing a considerable amount of labor in the metropolitan regions of the country, and presenting major challenges for public health, specifically in the field of occupational health. . In this sense, the issue of occupational safety can be a major problem, especially with regard to accidents at work.

The civil construction sector has sought to rationalize and standardize its production processes, which, through quality and productivity programs, achieve satisfactory results that lead to the elimination or minimization of problems encountered during project execution [17]. Thus, the production process needs quality programs to carry out its projects efficiently, that is, minimizing the problems encountered in the works.

The construction industry grows significantly and thus increases the demand for cement products, resulting in increased production in the concrete artifact industries that are not always prepared in the same proportion structurally and managerially to provide adequate conditions for the worker. health, safety and work environment [18]. In this sense, the need for the introduction and use of tools that help in the prevention of work accidents needs to be seen very rigorously in the works, as well as in the construction of slabs.

According to [19] "Brazil still remains one of the countries with one of the highest rates of occupational accidents in the world". According to the Statistical Yearbook of the International Labor Organization [20], Brazil occupies the eighth position in number of accidents and the fourth position in relation to accidents with death. In several ILO participating countries, construction, among all human activities, appears to have a self-reported degree of occupational accidents.

Due to the great risk that the construction industry brings to the worker, some protective measures will have to be taken, especially regarding the use of adequate equipment with regard to occupational safety [21].

According to [19], it indicates that NR 6 requires construction companies to distribute Personal Protective Equipment (PPE) to construction workers. The goal is to safeguard the physical health and integrity of employees.

Thus, it is the obligation of the worker to use the equipment correctly throughout the work period, and to ensure its maintenance.

The Standard also specifies the types of PPE that should be used to prevent various accidents and impacts on the eyes, ears, trunk, head, upper limbs, lower limbs and respiratory tract [19]. Especially prevents when work is performed on slab construction or heights above 2 meters.
Civil construction in general has been improving in relation to safety management standards and systems, but it is necessary to implement, comply with the rules, train, raise awareness and seek better results in relation to accidents in this sector [18]. Thus, the investment in safety and health of the worker of this industrialization does not grow at the same speed as the technological advance, but there have been improvements in the construction sector with regard to safety management.

For [19] NR 8 establishes the minimum technical requirements that must be present in buildings, aiming to ensure the safety and comfort of those who are working in construction. Thus, for floors, stairs, ramps and work place passages, for example, non-slip materials or processes should be used.

The documents required by NR-18 in item 18.3.4 referring to falls from a height are: project to implement collective protections in accordance with the stages of execution of the work and technical specification of collective and individual protections to be used [22].

NR 35 establishes the requirements for the safety of activities performed at heights - that is, those performed above two meters above ground level, where there is a risk of falling [19]. The author also points to NR 18 which is one of the main standards of construction. It establishes administrative, planning and organizational guidelines for the implementation and control of security systems.

For [23], the concreting of a slab with supply of machined concrete. In this activity, in addition to exposure to weather, there is the danger of working at heights on an uneven surface and the use of concrete pumping equipment (hose) .The assembly of precast slabs comprises the danger of handling the joists and working at heights. . Mounting the shoring mainly involves the hazards associated with carpentry.

According to [24], he points out that the most commonly used Personal Protective Equipment (PPE) is helmets and gloves, leaving behind ear and face protectors, seat belts and special shoes. However, it is mandatory for construction workers, as well as for works such as slabs under construction, thus avoiding accidents with the worker.

\section{MATERIAL AND METHODS}

Literature review was conducted from June 2019 to September 2019, which addressed the theme: Application of Occupational Safety Standards in Lajes Construction.

The search was carried out in the following databases: Virtual Electronic Scientific Library (SCIELO), academic websites, as well as books and magazines that portray this theme. To refine the search, the following keywords were used to search the sites: NR; Construction; Slabs.

The inclusion criterion was based on the abstract literature to classify the eligible articles, where only proposed to analyze the theme as broadly as possible, free articles were found 23 , and 4 were excluded because they had similar data and information, in Portuguese and / or Spanish. Also, in this stage, 13 articles in limited languages were excluded such as: (Russian, Hebrew, among others) and those with paid access.

The application of the research study will be presented through photos, as well as the data found in the literature review. The results will be presented based on the findings of the application. 


\section{STUDY APPLICATION}

Brazil has a very worrying rate of occupational accidents, as it is in the eighth position according to the International Labor Organization (ILO). In several ILO participating countries, construction, among all human activities, appears to have a selfreported degree of occupational accidents.

The need to use tools that help in the prevention of work accidents needs to be seen very rigorously in the works, as well as in the construction of slabs.

The NRs require construction companies to use the PPE, the workers, so that they can be protected from future accidents, as well as their physical integrity as a whole. Thus, it is the obligation of the worker to use the equipment correctly throughout the work period, and take care of their equipment.

Floors above 2 meters require workers to be equipped with adequate PPE to avoid impact should an accident occur. as shown in (Figure 1).

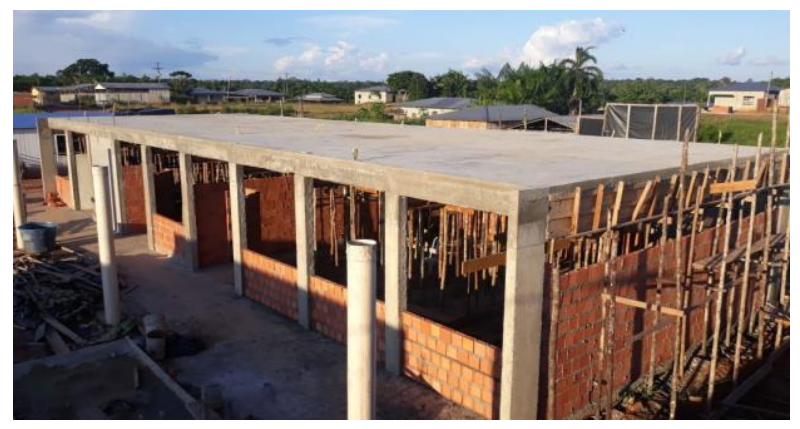

Figure 1: Construction of Slabs. Source: Authors, (2019).

NR 35 establishes that above 2 meters the proper equipment must be used due to the height of the work environment, NR 18 which is one of the main Building Standards, establishes administrative, planning and organizational guidelines for the implementation and control of security systems as a whole, as shown in (figure 2).

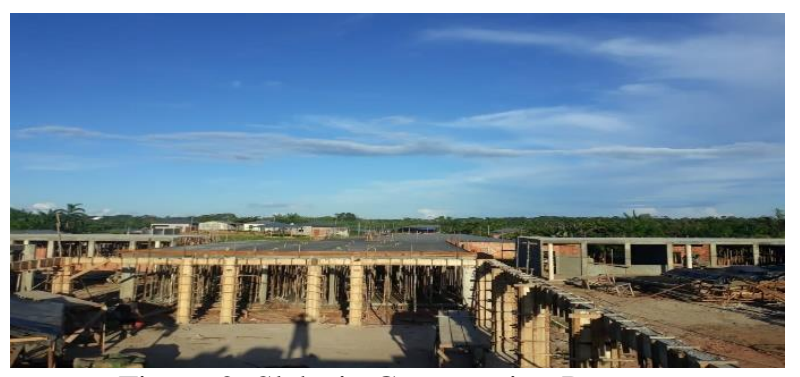

Figure 2: Slabs in Construction Process. Source: Authors, (2019).

Thus, the standard aims to prevent accidents and falls from requirements such as: Training and qualification; Personal protective equipment, accessories and anchor systems; Emergency team Including slab design executions, as these are works above two meters above ground level.

The assembly of precast slabs requires carpenters to be equipped with their proper equipment so that no accidents occur in the slab carpentry process, as shown in (Figure 3 ).

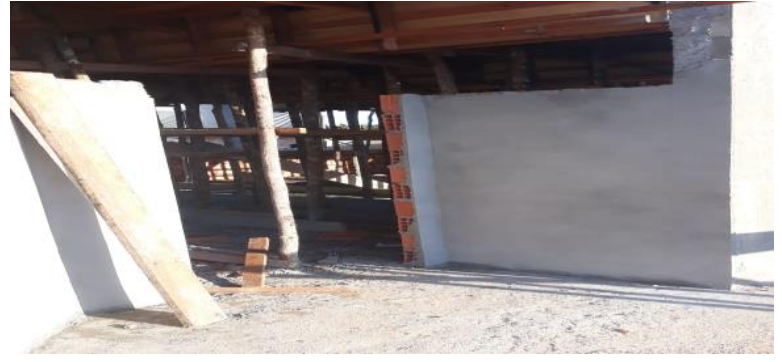

Figure 3: Slab Shoring Assembly. Source: Authors, (2019).

Disassembly also presents the risk of collapse of the slab or part of it and the fall of other materials used. Sometimes causing an accident if workers do not have adequate PPE. In these cases, the use of PPE is very important, such as helmets and gloves, ear and face protectors, seat belts and special shoes.

\section{RESULTS AND DISCUSSION}

The contractors have invested heavily in the safety of workers, but it is observed that sometimes the owners themselves do not value such investment, as they sometimes stop using the equipment and end up exposing themselves to accidents, due to the non-use of PPE. Continued use of PPE makes professionals safer in performing the activities they are performing.

Companies are responsible for ongoing oversight so that workers are properly using PPE in the workplace, especially in high places.

With the use of these protective equipment, the rate of accidents on the construction site decreases, as well as the leaves, since workers are able to perform their work more safely. In this sense, both the workers and the person in charge of the construction work gain, since accidents only delay construction work.

The use of NRs guarantees the worker safety, as well as guarantees the delivery of construction that can be slabs, among others, on time, so that companies have more success and more contracts, as well as jobs, moving the economy of the labor market. country in this sector.

\section{FINAL CONSIDERATIONS}

The study showed the growth of the construction industry in recent years in Brazil, but also noted that the problems regarding worker safety also increased.

With regard to accidents at the construction work environment, he noted that this is due to employers' negligence in providing unsafe working conditions and the neglect and inattention of employees who commit unsafe acts.

With regard to the existing standards that protect the worker, this needs to be encouraged, as well as perform training, and require the sector supervisor to use PPE in all sectors in the construction of the work, and especially works at heights, i.e. in slabs.

Regarding the Lajes constructions, he observed that the standards exist, but noted that sometimes the workers themselves do not use PPE, leaving them vulnerable to accidents in the workplace.

The study presented is very relevant and can be used for future scientific research, as well as contributing to new discoveries in academia. 


\section{REFERENCES}

[1] Leão, M. V. M. Análise da qualificação da mão de obra no setor da construção civil na cidade de Dourados (MS). 2016. 47 páginas. Trabalho de Conclusão de Curso (Bacharelado) - Universidade Tecnológica Federal do Paraná. Campo Mourão, 2016.

[2] Mattos, A. D. Planejamento e controle de obras (1. ed.). São Paulo: 2010.

[3] Josefi, James; Chemin, Acylino; Mendes, Cristiane Ansbach Pereira. Formação ]e Qualificação da Mão de Obra Na Construção Civil. Ponta Grossa - PR, 2010.

[4] Silva, Jaqueline Luisa. Aplicação das Ferramentas da Qualidade para Melhoria de Processos Produtivos Estudo de Caso em um Centro Automotivo. Joinville, SC- 2017.

[5] Carvalho, Bruno Franklin Moreira. Capacitação de Mão de Obra Para a Construção Civil. Fortaleza, 2011.

[6] Fagundes, J. R. et al. Análise das metas do Programa Nacional de Habitação Rural (PNHR) no contexto nacional. Revista do Desenvolvimento Regional - Faccat, Rio Grande do Sul, n.2, jul/dez 2013.

[7] Ferreira, André Viola; Zancul, Eduardo. Estudo sobre produtividade na construção civil: desafios e tendências no Brasil. Editora: EYGM Limited. São Paulo, 2014.

[8] Silva, Cínthia Figueira da. Análise de Falhas em Projetos de Construção Civil. Belo Horizonte- MG, 2015.

[9] Oliveira, Cristiane S. P. As principais características da mãode-obra da construção civil que interferem na filosofia da qualidade. 87 f. Curso de Pós-Graduação em Engenharia de Produção. Universidade Federal de Santa Maria, Santa Maria, 2001.

[10] Silva, Antonio Bertoldo da; Maciel, Jussara Cury Socorro. Viabilidade técnica da utilização de concretos com agregados reciclados de resíduos de construção e demolição. REVISTA IGAPÓ-Revista de Educação Ciência e Tecnologia do IFAM, 2014, 3.

[11] De Resende, Carlos César Rigueti. Atrasos de obra devido a problemas no Gerenciamento. 2013. PhD Thesis. Universidade Federal do Rio de Janeiro.

[12] Moraes, Ana Beatriz G. M., ET AL. Fatores críticos da gestão do processo de projetos na engenharia simultânea: um estudo de caso em obra de infraestrutura urbana. VIII Congresso Nacional de Excelência em Gestão: IBMEC, 2012.

[13] Calçada, Paulo de Azevedo Branco. Estudo dos processos produtivos naconstrução civil objetivando ganhos de produtividade e qualidade. Rio deJaneiro: EP/UFRJ, 2014.

[14] Guimaraes, David Bernar Oliveira.et, al.Saúde e Segurança na Construção Civil: Relato Sobre as Contribuições da Enfermagem.Revenferm UFPE online., Recife, 11(Supl. 3):13519, mar., 2017.
[15] Simões Tc, et, al. Souza Nvdo, Shoji S, Peregrino Aaf, Silva D. Medidas de prevenção contra câncer de pele em trabalhadores da construção civil: contribuição da enfermagem. Rev Gaúcha Enferm [Internet]. 2011.

[16] Jab, Iriart, Oliveira RP, Xavier SS, Costa MAS, Araújjo GR, Santana VS. Representações do trabalho informal e dos riscos à saúde entre trabalhadoras domésticas e trabalhadores da construção civil. Ciênc SaúdeColet. 2008;13(1):165-74.

[17] Barra, Renata Brabo Mascarenhas, et al. Avaliação da qualidade de serviços logísticos em processos construtivos de unidades habitacionais do programa nacional de habitação rural. Revista Gestão Industrial, 2015, 11.2.

[18] Holleben, Mildre Von; Catai, Rodrigo Eduardo; Amarilla, Rosemara Santos Deniz. Gestão de Riscos: Análise Preliminar de Riscos na Produção de Estruturas Pré-Fabricadas de Concreto. Paraná- 2012.

[19] Alves, Nadine. As principais Normas Regulamentadoras da construção civil (NR’s). 2018.

[20] OIT - Organização Internacional do Trabalho 2009 Estatística de Acidentes de Trabalho no Mundo.

[21] Martins, Miriam Silvério. Diretrizes para elaboração de medidas de prevenção contra quedas de altura em edificações. São Carlos: UFSCar, 2005.

[22] Mota, Rodrigo Gonçalves. Acidentes na construção civil em 2012 já superam todo 2011.

[23] Machado, Daniela Bastian. Segurança do trabalho na construção civil: Um estudo de caso. 2015.

[24] Silveira, Cristiane Aparecida et al. Acidentes de trabalho na construção civil identificados através de prontuários hospitalares. Rem: Revista Escola de Minas, v. 58, n. 1, p. 39-44, 2005. 